Substance A was isolated with a yield of $15 \%$ from the combined $A, B$, and $C$ by column chromatography on hydrated silica in the system mentioned above. Substance A gave a single spot on chromatography in a thin layer of KSK silica gel and hydrated silica in neutral, acid, and alkaline systems: chloroform-methanol-water $(62: 31: 7)$, 1-butanol-acetic acid-water $(4: 1: 2)$; and $n$-propanol-17\% ammonia $(8: 2)$. The $\mathrm{R}_{f}$ values of substance $A$, its melting point (about $250^{\circ} \mathrm{C}$ ), the melting point of the acetate $\left(160-163^{\circ} \mathrm{C}\right)$, and the IR spectrum were identical with the same figures for samples of Primula saponin given to us by N. I. Libizov (VILR [All-Union Scientific-Research Institute for Medicinal and Aromatic Plants]).

The full tridecaacetate of substance A, recrystallized from a mixture of petroleum ether and ether had mp $160.5-163^{\circ} \mathrm{C}$.

Found, \%: C 58.20; H 7.17, Calculated for $\mathrm{C}_{80} \mathrm{H}_{114} \mathrm{O}_{36}, \%$ : C 58.17; $\mathrm{H} 6.96$.

The melting point of the full acetate that we obtained from a sample of Primula saponin was $157-150^{\circ} \mathrm{C}$. A mixture of the acetates gave no depression of the melting point. The IR spectra were identical.

The thin-layer chromatogram on silica gel $\mathrm{G}$ of the water-insoluble products of hydrolysis of substance A corresponded to that reported for Primula saponin [1]. The monosaccharides obtained on hydrolysis were identified by means of paper chromatography as galactose, glucose, rhamnose, and uronic acid. An analysis of the monosaccharides formed during hydrolysis shows that uronic acid split off last. This shows that it is attached directly to the genin.

All these data correspond to those reported previousiy for Primula saponin and, thus, the saponin from Primula turkestanica is also $3\{[\beta-D$ glucopyranosyl- $(1 \rightarrow 6)-\beta-D$-galactopyranosyl $(1 \rightarrow 4)]-[\alpha-L$-rhamnopyranosyl $(1 \rightarrow 2)]-\beta$ D-galacturopyranosyl-(1)\} primulagenin $\mathrm{A}$.

When a mixture of substances A, B, and C was chromatographed together with substance A, a mixture of $B$ and $C$ was obtained from which recrystallization from methanol gave substance $B$ with $\mathrm{mp} 183.5-185^{\circ} \mathrm{C}$, which was identified as sucrose.

REFERENCE:

1. R. Tschesche and F. Ziegler, Ann. Chem. 674, 185, 1964.

14 June 1938

All-Union Scientific-Research Institute for Medicinal Plants

UDC $547.944 / 945$

\title{
A STUDY OF THE ALKALOIDS OF SENECIA KRYLOVII
}

L. A. Sapunova and A. I. Ban'kovskii

Khimiya Prirodnykh Soedinenii, Vol. 4, No. 6, p. 389, 1968

The epigeal part of Senecia krylovii was collected by V. B. Kubaev in Transbaikal at the end of the vegetation phase of the plant. The alkaloids were extracted from $450 \mathrm{~g}$ of raw material with a $4 \%$ solution of sulfuric acid with simultaneous reduction by means of zinc dust. The alkaloids were extracted with chloroform from the sulfuric acid extract after it had been made alkaline with ammonia. The chloroform extract was treated with a small amount of sulfuric acid solution. When the sulfuric acid extract was alkalized with ammonia to $\mathrm{pH} 8$, a white crystalline precipitate deposited. Yield $0.03 \%$. It was shown by thin-layer chromatography on silica gel in the systems 1) methanol, and 2) diethyl ether-chloroform-diethylamine $(8: 2: 1)$ that it consisted of a single base with $R_{f}$ values 0.60 and 0.50 , respectively. After recrystallization from methanol, the melting point of the base was $\left.214-212^{\circ} \mathrm{C} ; \alpha\right]_{\mathrm{D}}^{20}-139^{\circ}$ (c 0.71 ; chloroform); composition $\mathrm{C}_{18} \mathrm{H}_{25} \mathrm{O}_{5} \mathrm{~N}_{\text {; }}$ melting point of the picrate $180-181^{\circ} \mathrm{C}$ and of the picrolonate $187-$ $189^{\circ} \mathrm{C}$. A mixture of the substance was obtained with an authentic sample of seneciphylline gave no depression. The IR spectrum of the base was identical with that of seneciphylline. 